on 'Abas', but this cultivar is one that is noted for its extreme biennial-bearing characteristics. Ethephon also had no influence on return bloom of 'Abas'. BA did not increase flowering in one experiment with 'Redspur Delicious', but crop load the previous year was so low that even control trees returned with a heavy bloom.

\section{Literature Cited}

Denne, M.P. 1963. Fruit development and some tree factors affecting it. New Zealand J. Bot. 1:265-294.

Forshey, C.G. 1987. A review of chemical fruit thinning. Proc. Mass. Fruit Growers' Assn. 93:68-73.

Greene, D.W. and W.R. Autio. 1988. chemical thinning of apples. Univ. of Mass. Coop. Ext. Bul. L-544.

Greene, D.W. and W.R. Autio. 1989. Evaluation of benzyladenine as a chemical thinner of 'McIntosh' apples. J. Amer. Soc. Hort. Sci. 114:68-73.

Herrera-Guirre, F. and C.R. Unrath. 1980. Chemical thinning response of Delicious apples to volume of applied water. HortScience 15:4344.

Holder, P.A., G.W. Eaton, and H.I. Ridenour. 1982. Thinning 'McIntosh' apples in British Columbia. Scientia Hort. 16:233-238.

Letham, D.S. 1969. Regulators of cell division of plant tissues. 6. The effects of zeatin and other stimulants of cell division on apple fruit development. New Zealand J. Agr. Res. 12:1-20.

Looney, N.E. 1986. Chemical thinning of apple: Some new strategies and important refinements to old procedures. Acta Hort. 179:597604.

McLaughlin. J.M. and D.W. Greene. 1984. Effects of BA, GA ${ }_{4+7}$ and daminozide on fruit set, fruit quality, vegetative growth, flower initiation and flower quality of 'Golden Delicious' apples. J. Amer. Soc. Hort. Sci. 109:34-39.

Unrath, C.R. 1974. The commercial implications of gibberellins $\mathrm{A}_{4+7}$ plus benzyladenine for improving shape and yield of 'Delicious' apples. J. Amer. Soc. Hort. Sci. 99:381-384.

Williams, M.W. and L.J. Edgerton. 1981. Fruit thinning of apples and pears with chemicals. USDA Agr. Info. Bul. 289.

J. AMER. Soc. Hort. SCI. 115(3):400-404. 1990.

\title{
Vegetative Responses of Apple Trees Following Benzyladenine and Growth Regulator Sprays
}

\begin{abstract}
Duane W. Greene and Wesley R. Autio
Department of Plant and Soil Sciences, University of Massachusetts, Amherst, MA 01003

Additional index words. Malus domestica, BA, daminozide, carbaryl, spur quality, thinning, fruit set, bioregulator

Abstract. Benzyladenine (BA) stimulated lateral branching on young apple (Malus domestica Borkh.) trees at concentrations as low as $100 \mathrm{mg} \cdot \mathrm{liter}^{-1}$. BA reduced lateral shoot length indirectly through increased intersboot competition, whereas daminozide reduced lateral shoot growth as a direct effect of the chemical inhibition. Daminozide reduced the number of spurs that were induced by BA to grow into lateral shoots. BA reduced the size of terminal buds on spurs that were stimulated to grow into lateral shoots. When daminozide was included with BA, spur quality was increased, as determined by Increased bud size. The positive effect of daminozide on BA-treated spurs was indirect, and other growth retardants used in combination with BA may be equally effective at improving spur quality. It may not be possible to stimulate lateral branching with BA on young trees just coming into production without causing an unacceptable amount of thinning. However, on bearing 'Empire' trees, lateral shoot growth was increased with BA while still achieving an appropriate level of thinning. In general, there was no advantage to applying BA in a split application. Chemical names used: N-(phenylmethyl)-1H-purine-6-amine [benzyladenine (BA)]; butanedioic acid mono(2,2-dimethylhydrazide) (daminozide).
\end{abstract}

Benzyladenine (BA) alone or in combination with GA.,+, increased lateral branching on young apple trees (Elfving, 1984; Forshey, 1982; Greene and Miller, 1988; Miller and Eldridge, 1986). These studies were performed on young, sparsely branched trees with the specified purpose of increasing potential bearing surface by stimulating lateral branch development. As trees come into production, emphasis generally shifts from enhanced canopy development to stimulation of flowering and spur development. BA induced lateral branching in 4-year-old 'Macspur McIntosh' at concentrations up to $500 \mathrm{mg} \cdot \mathrm{liter}^{-1}$, but crop load was reduced (Greene and Autio, 1989).

Branching can be promoted by BA at concentrations as low as $100 \mathrm{mg} \cdot$ liter $^{-1}$ (Greene and Miller, 1988; Greene and Autio, 1989). However, the branching response may be either modified or eliminated by other factors, such as the presence of fruit on the treated limbs (Kender and Carpenter, 1972).

Received for publication 24 Apr. 1989. Paper no. 2925, Massachusetts Agricultural Experiment Station, Univ. of Massachusetts at Amherst. The cost of publishing this paper was defrayed in part by the payment of page charges. Under postal regulations, this paper therefore must be hereby marked advertisement solely to indicate this fact.
The importance of strong, vigorous spurs for flower bud formation, fruit set, and fruit size has been recognized for many years (Yeager, 1916). The influence of light levels, spur age, and canopy position have been studied, especially on older spurtype trees (Barritt et al., 1987). Growth regulators may also influence spur vigor. Foliar sprays of aminoethoxyvinylglycine (AVG) increased bud size and leaf area on young 'Delicious' trees (Greene, 1983). BA application increased flower number and survival of king flowers following a frost on 'Golden Delicious' trees (McLaughlin and Greene, 1984).

This study was undertaken to determine the growth and spur quality responses following application of BA or BA-growth regulator combinations on bearing apple trees or trees that were just starting to come into production.

\section{Materials and Methods}

\section{Bearing trees}

Experiment 1. 'Empire'/MM.106, Belchertown, Mass. A block of mature 'Empire' trees were selected, and whole trees were treated with $\mathrm{BA}$ at 0,100 , or $200 \mathrm{mg} \cdot \mathrm{liter}^{-1}$ or carbaryl at 0 or $600 \mathrm{mg} \cdot \mathrm{liter}^{-1}$, alone or in combination. The experimental de- 
sign was a randomized complete block with seven replications (Greene et al., 1990). After leaf abscission in the fall, two limbs, 7.5 to $10 \mathrm{~cm}$ in circumference, per tree were selected; the circumferences were measured, and then the length of all terminal and lateral shoots were measured. A terminal was defined as a shoot that originated from a shoot that grew $5 \mathrm{~cm}$ or more the previous year; a lateral was defined as a shoot that grew $5 \mathrm{~cm}$ or more and originated from a spur or shoot that grew $<5 \mathrm{~cm}$ the previous year.

\section{Trees just coming into production}

Experiment 2. 'Mutsu'/'M.7, Brookfield, Mass. A block of 6year-old 'Mutsu' trees was partitioned into seven blocks (replications) of eight trees each. Twelve days after full bloom, seven trees in each block were sprayed with daminozide at 1500 $\mathrm{mg} \cdot \mathrm{liter}^{-1}$. For six of the daminozide-treated trees, BA was included at 50, 100, or $200 \mathrm{mg} \cdot \mathrm{liter}^{-1}$ (two trees treated per level). Three weeks after the first application, the BA treatment was repeated on one of the BA-treated trees. Terminal and lateral shoot growth on two limbs per tree were measured, as described in Expt. 1. Following termination of growth in the fall, 20 spurs per tree were collected from 2-year-old wood and then weighed. The terminal bud was cut off, its diameter measured using a caliper, and the composite sample from the tree was weighed.

Experiment 3. 'Redspur Delicious'/M.7, Belchertown, Mass. Four-year-old trees were partitioned into seven blocks (replications) of eight trees each. Thirteen days after full bloom, four trees in each block were sprayed to the drip point with $1500 \mathrm{mg}$ daminozide/liter. One tree sprayed with daminozide and one unsprayed tree in each block were treated with BA at $0,75,150$, or 300 $\mathrm{mg} \cdot$ liter $^{-1}$. Vegetative growth on two selected limbs per tree was assessed as described in Expt. 1, and spur characteristics of 20 spurs per tree were evaluated as described in Expt. 2.

Experiment 4. 'Redspur Delicious'/MM.111, Belchertown, Mass. Five-year-old trees were partitioned into seven blocks (replications) of six trees each. Ten days after full bloom, three trees in each block were sprayed to the drip point with 1500 $\mathrm{mg}$ daminozide/liter. Of the trees sprayed with daminozide, and those not sprayed, one each was then treated with BA at 0,150 , or $300 \mathrm{mg} \cdot \mathrm{liter}^{-1}$. Vegetative growth on two limbs per tree and characteristics of 20 spurs per tree were determined as previously described.

All data were subjected to analysis of variance. Where interactions were nonsignificant, only main effect means arc presented. Those means were separated by $F$ test or single-dcgreeof-freedom orthogonal comparisons, depending on the number of levels in the experiment. In Expt. 2, single-degree-of-freedom linear comparisons were also used to separate means.

\section{Results}

BA at 100 and $200 \mathrm{mg} \cdot$ liter $^{-1}$ thinned 'Empire' fruit and significantly increased lateral branching (Table 1). The average lateral shoot extension was reduced by the BA treatments, although total elongation of lateral shoots was substantially increased, due primarily to the increased numbers of lateral branches. BA had no influence on terminal growth, and increases in total growth were caused by the increased number of spurs that were stimulated to grow into lateral shoots.

One application of BA at concentrations up to $200 \mathrm{mg} \cdot \mathrm{liter}^{-1}$ applied with daminozide was not sufficient to increase lateral branching, although mean lateral and terminal growth of 'Mutsu' were reduced (Table 2). Increased lateral branching, terminal growth, and total growth followed a second BA application. One application of BA was insufficient to influence spur weight, although bud weight and bud diameter were substantially increased. The second BA application caused an increase in spur weight, but bud weight and bud diameter were significantly reduced. BA caused fruit thinning, although two applications were no more effective than one.

Daminozide resulted in a decrease in lateral branching, whereas BA caused a linear increase (Tables 3 and 4). There was a significant $\mathrm{BA} \times$ daminozide interaction on lateral branching. BA increased lateral branching on 'Redspur Delicious' when BA was applied in the absence of daminozide (Fig. 1 A and B). When applied with daminozide, it had a greatly diminished effect on lateral branching. Both BA and daminozide reduced the extension of lateral shoots (Tables 3 and 4) and the length of terminal shoots (Table 4).

There was a daminozide $\times$ BA interaction on terminal growth. BA applied alone reduced terminal growth (Table 4). When BA and daminozide were applied together, it appeared that BA had

Table 1. Effects of carbaryl alone and in combination with benzyladenine (BA) on fruit set and shoot growth of 'Empire'/MM.106. Expt. 1. ${ }^{\mathrm{z}}$

\begin{tabular}{|c|c|c|c|c|c|c|c|}
\hline \multirow[b]{2}{*}{$\begin{array}{l}\text { Treatment } \\
\left(\mathrm{mg} \cdot \text { liter }^{-1}\right)\end{array}$} & \multirow[b]{2}{*}{$\begin{array}{l}\text { Fruit/cm } \\
\text { limb } \\
\text { circumf. }\end{array}$} & \multicolumn{3}{|c|}{ Lateral shoots } & \multicolumn{2}{|c|}{ Terminal shoot } & \multirow[b]{2}{*}{$\begin{array}{c}\text { elongation } / \mathrm{cm} \\
\operatorname{limb} \\
\text { circumf. }\end{array}$} \\
\hline & & $\begin{array}{l}\text { No./cm } \\
\text { limb } \\
\text { circumf. }\end{array}$ & $\begin{array}{c}\text { Mean } \\
\text { length } \\
(\mathrm{cm})\end{array}$ & $\begin{array}{c}\text { Total } \\
\text { elongation } / \mathrm{cm} \\
\text { limb circumf. }\end{array}$ & $\begin{array}{c}\text { Mean } \\
\text { length } \\
(\mathrm{cm})\end{array}$ & $\begin{array}{c}\text { Total } \\
\text { elongation } / \mathrm{cm} \\
\text { limb circumf. }\end{array}$ & \\
\hline \multicolumn{8}{|l|}{ Carbaryl } \\
\hline $\begin{array}{r}0^{0} \\
600\end{array}$ & $\begin{array}{l}5.9 \\
4.3\end{array}$ & $\begin{array}{l}1.9 \\
1.8\end{array}$ & $\begin{array}{l}15.1 \\
13.3\end{array}$ & $\begin{array}{l}26.5 \\
23.7\end{array}$ & $\begin{array}{l}39.6 \\
36.1\end{array}$ & $\begin{array}{l}12.1 \\
13.7\end{array}$ & $\begin{array}{l}38.6 \\
37.4\end{array}$ \\
\hline $\begin{array}{r}0 \\
100 \\
200\end{array}$ & $\begin{array}{l}7.6 \\
4.8 \\
2.9\end{array}$ & $\begin{array}{l}0.9 \\
1.4 \\
3.3\end{array}$ & $\begin{array}{l}16.9 \\
13.8 \\
11.9\end{array}$ & $\begin{array}{l}16.0 \\
19.7 \\
39.6\end{array}$ & $\begin{array}{l}36.5 \\
39.5 \\
37.5\end{array}$ & $\begin{array}{l}11.8 \\
12.9 \\
14.1\end{array}$ & $\begin{array}{l}27.8 \\
32.6 \\
53.7\end{array}$ \\
\hline \multicolumn{8}{|l|}{ Significance } \\
\hline $\begin{array}{l}\text { Carbaryl } \\
\text { BA } \\
\text { Linear } \\
\text { Quadratic } \\
\text { BA x carbaryl }\end{array}$ & $\begin{array}{l}* \\
* * * \\
\text { NS } \\
\text { NS }\end{array}$ & $\begin{array}{l}\text { NS } \\
* \cdots * \\
* * * \\
\text { NS }\end{array}$ & $\begin{array}{l}* \\
\text { NS } \\
\text { NS }\end{array}$ & $\begin{array}{c}\text { NS } \\
* * * \\
* * * \\
* \\
\text { NS } \\
\end{array}$ & $\begin{array}{c}* \\
\text { NS } \\
\text { NS } \\
\text { NS } \\
\text { NS }\end{array}$ & $\begin{array}{l}\text { NS } \\
\text { NS } \\
\text { NS } \\
\text { NS } \\
\text { NS }\end{array}$ & $\begin{array}{c}\text { NS } \\
* * * \\
* * * \\
* \\
\text { NS }\end{array}$ \\
\hline
\end{tabular}

${ }^{\mathrm{z}}$ Means of 42 (carbaryl) or 28 (BA) observations.

${ }^{*, * *, * * *, N S}$ Significant at $P=0.05,0.01$, or 0.001 , or not significant, respectively. 
Table 2. Effects of daminozide at $1500 \mathrm{mg} \cdot \operatorname{liter}^{-1}$ and benzyladenine (BA) combinations on fruit set, growth, and spur quality of 'Mutsu'/M.7 apple trees. Expt. 2.

\begin{tabular}{|c|c|c|c|c|c|c|c|c|c|}
\hline \multirow{2}{*}{$\begin{array}{l}\text { Treatment } \\
(\text { mg-liter }\end{array}$} & \multirow[b]{2}{*}{$\begin{array}{l}\text { No. BA } \\
\text { applications }\end{array}$} & \multirow[b]{2}{*}{$\begin{array}{l}\text { Fruit/cm } \\
\text { limb } \\
\text { circumf. }\end{array}$} & \multicolumn{2}{|c|}{ Lateral shoots } & \multirow{2}{*}{$\begin{array}{l}\text { Terminal } \\
\text { growth } \\
\text { mean } \\
\text { length } \\
\text { (cm) }\end{array}$} & \multirow{2}{*}{$\begin{array}{c}\text { Total } \\
\text { elongation/cm } \\
\text { limb } \\
\text { circumf." }\end{array}$} & \multicolumn{3}{|c|}{ Spur characteristics } \\
\hline & & & $\begin{array}{l}\text { No./cm } \\
\operatorname{limb} \\
\text { circumf.2 }\end{array}$ & $\begin{array}{l}\text { Mean } \\
\text { length } \\
(\mathrm{cm})^{y}\end{array}$ & & & $\begin{array}{c}\text { Spur wt } \\
\text { (mg) }^{\mathbf{v}}\end{array}$ & $\begin{array}{l}\text { Bud wt } \\
(\mathrm{mg})^{v}\end{array}$ & $\begin{array}{c}\text { Bud } \\
\text { diam } \\
(\mathbf{m m})^{v}\end{array}$ \\
\hline $\begin{array}{l}\text { Control } \\
\text { Daminozide alone } \\
+ \text { BA } 50 \\
+ \text { BA } 100 \\
+ \text { BA } 200 \\
+ \text { BA } 50 \\
\text { + BA } 100 \\
\text { + BA 200 } \\
\text { Significance }\end{array}$ & $\begin{array}{l}- \\
-1 \\
1 \\
1 \\
2 \\
2 \\
2\end{array}$ & $\begin{array}{l}2.7 \\
2.4 \\
1.8 \\
1.7 \\
1.1 \\
1.7 \\
1.5 \\
0.9 \\
* * *\end{array}$ & $\begin{array}{l}0.8 \\
1.1 \\
0.6 \\
0.9 \\
1.2 \\
0.9 \\
1.6 \\
3.6 \\
* * *\end{array}$ & $\begin{array}{l}17.2 \\
11.7 \\
14.2 \\
12.8 \\
13.1 \\
11.2 \\
12.7 \\
12.4 \\
\end{array}$ & $\begin{array}{l}35.1 \\
24.8 \\
22.6 \\
26.6 \\
25.4 \\
22.7 \\
26.9 \\
32.5 \\
2.4\end{array}$ & $\begin{array}{l}43.2 \\
32.1 \\
29.1 \\
34.6 \\
35.8 \\
31.0 \\
44.0 \\
71.7 \\
4 * 4\end{array}$ & $\begin{array}{r}670 \\
630 \\
650 \\
800 \\
860 \\
810 \\
1280 \\
2050 \\
* * *\end{array}$ & $\begin{array}{r}73 \\
93 \\
111 \\
113 \\
121 \\
120 \\
105 \\
85 \\
.\end{array}$ & $\begin{array}{l}4.0 \\
4.6 \\
4.9 \\
4.9 \\
5.2 \\
5.0 \\
4.9 \\
4.6 \\
* * *\end{array}$ \\
\hline Daminozide + BA & 1 & & & & & & & & \\
\hline $\begin{array}{l}\text { Linear } \\
\text { Quadratic }\end{array}$ & & *** & $\begin{array}{l}\text { NS } \\
\text { NS }\end{array}$ & $\begin{array}{l}\text { NS } \\
\text { NS }\end{array}$ & $\begin{array}{l}\text { NS } \\
\text { NS }\end{array}$ & $\begin{array}{l}\text { NS } \\
\text { NS }\end{array}$ & $\begin{array}{l}\text { NS } \\
\text { NS }\end{array}$ & NS & NS \\
\hline $\begin{array}{l}\text { Daminozide + BA } \\
\text { Linear }\end{array}$ & 2 & $\bullet$ & $* *$ & NȘ & $* *$ & $\bullet *$ & $\cdots$ & $\bullet$ & NS \\
\hline $\begin{array}{l}\text { Quadratic } \\
\text { BA } 1 \times \text { vs. BA } 2 \times\end{array}$ & & $\begin{array}{l}\text { NS } \\
\text { NS }\end{array}$ & $\because$ & $\begin{array}{l}\text { NS } \\
\text { NS }\end{array}$ & $\begin{array}{l}\text { NS } \\
\text { NS }\end{array}$ & NS & NS & $*$ & $*$ \\
\hline BA $1 \times$ vs. control & & $* * *$ & NS & $\cdots$ & $* *$ & NS & NS & *** & $* * *$ \\
\hline BA $2 \times$ vs. control & & $* * *$ & $* * *$ & $* * *$ & $* * *$ & NS & $* *$ & $* * *$ & $* * *$ \\
\hline $\begin{array}{l}\text { Daminozide vs. control } \\
\text { BA } 1 \times \text { vs. BA } 2 \times\end{array}$ & & NS & NS & **** & $* *$ & NS & NS & - & $* * *$ \\
\hline (same amount BA) & & NS & NS & NS & NS & NS & NS & NS & NS \\
\hline $\begin{array}{l}\text { "Means of } 14 \text { observatio } \\
\text { Means of } \approx 350 \text { observ } \\
\text { Means of } \approx 40 \text { observa } \\
\text { "Means of } \approx 420 \text { observ } \\
\text { "Means of } 140 \text { observati }\end{array}$ & $\begin{array}{l}\text { ns. } \\
\text { s. } \\
\text { ns. }\end{array}$ & & . & & . & & & & \\
\hline
\end{tabular}

Table 3. Effects of benzyladenine (BA) and daminozide (D) on growth, lateral branching, and spur characteristics of 'Redspur Delicious'/M.7. Expt. 3.'

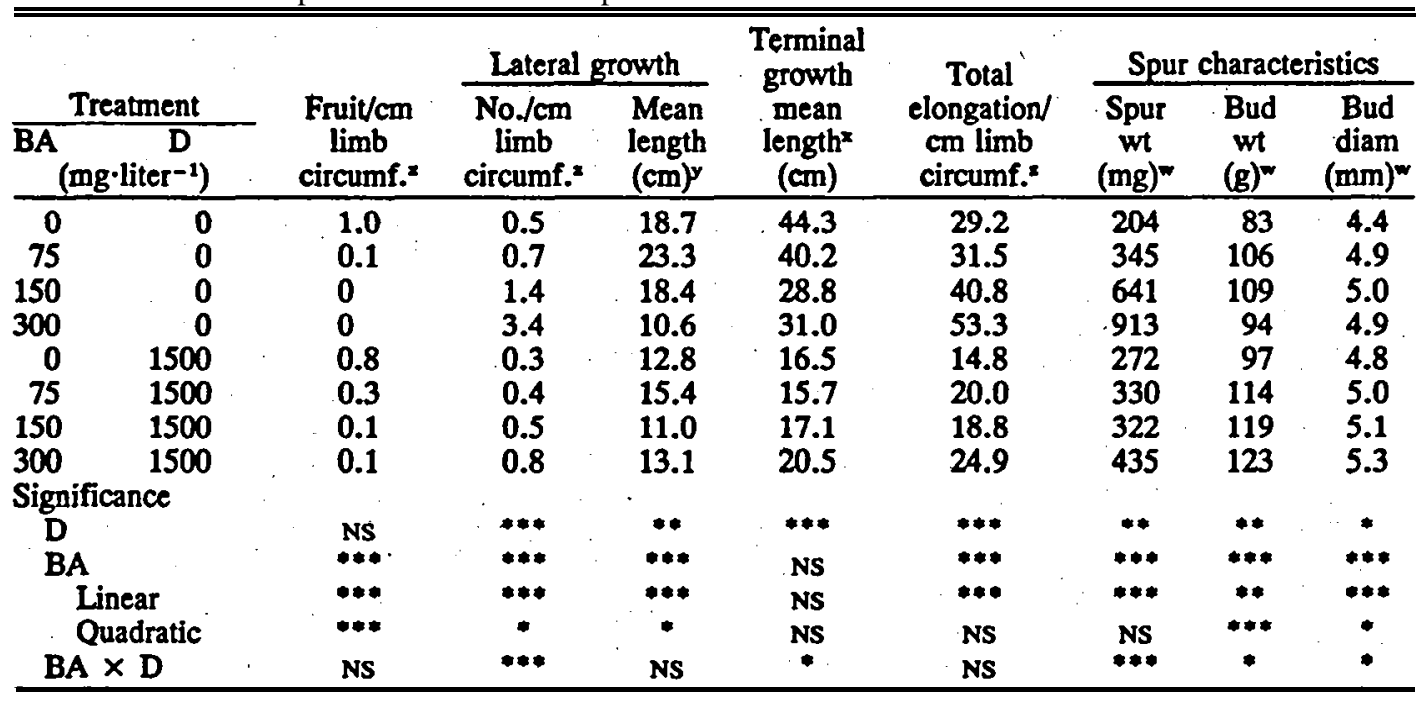

${ }^{\mathrm{z}}$ Means of 14 observations.

${ }^{\mathrm{y}}$ Means of $\approx 140$ observations.

${ }^{\mathrm{x}}$ Means of $\approx 70$ observations.

${ }^{\mathrm{w}}$ Means of 140 observations.

${ }^{*, * *, * * *, N S}$ Significant at $P=0.05,0.01$, or 0.001 , or not significant, respectively.

little effect on further reducing terminal growth beyond that obtained when daminozide was applied alone (Fig. $1 \mathrm{C}$ and D).

Both daminozide and BA, increased spur weight (Table 3).
The increase in spur weight following BA application was due primarily to stimulation of spurs to grow into lateral shoots. The absence of an effect of BA on spur weight in Expt. 4 is due to 
Table 4. Effects of benzyladenine (BA) and daminozide (D) on growth, lateral branching, and spur characteristics of 'Redspur Delicious'/M.111. Expt. 4.

\begin{tabular}{|c|c|c|c|c|c|c|c|c|c|}
\hline \multirow{2}{*}{\multicolumn{2}{|c|}{ Treatment }} & \multicolumn{3}{|c|}{ Lateral growth } & \multicolumn{2}{|c|}{ Terminal growth } & \multicolumn{3}{|c|}{ Spur characteristics } \\
\hline & & \multirow{2}{*}{$\begin{array}{l}\text { No./cm } \\
\text { limb } \\
\text { circumf. }\end{array}$} & \multirow{2}{*}{$\begin{array}{l}\text { Mean } \\
\text { length } \\
(\mathrm{cm})^{2}\end{array}$} & \multirow{2}{*}{$\begin{array}{c}\text { Total } \\
\text { elongation } / \mathrm{cm} \\
\text { limb circumf. }\end{array}$} & \multirow{2}{*}{$\begin{array}{l}\text { Mean } \\
\text { length } \\
(\mathrm{cm})^{x}\end{array}$} & \multirow{2}{*}{$\begin{array}{c}\text { Total } \\
\text { elongation } / \mathrm{cm} \\
\text { limb circumf. }\end{array}$} & \multirow{2}{*}{$\begin{array}{l}\text { Spur } \\
\text { wt } \\
(\mathrm{mg})^{w}\end{array}$} & \multirow{2}{*}{$\begin{array}{c}\text { Bud } \\
\text { wt } \\
(\mathrm{mg})^{w}\end{array}$} & \multirow{2}{*}{$\begin{array}{r}\text { Bud } \\
\text { diam } \\
(\mathrm{mm})^{\mathrm{w}}\end{array}$} \\
\hline BA & $\begin{array}{c}D \\
\left.e r^{-1}\right)\end{array}$ & & & & & & & & \\
\hline 0 & & 0.7 & 28.9 & 19.1 & 44.0 & 16.0 & 192 & 72 & 3.9 \\
\hline 150 & & 1.4 & 18.2 & 26.1 & 35.3 & 10.0 & 222 & 74 & 4.1 \\
\hline 300 & 0 & 2.0 & 15.9 & 30.4 & 35.1 & 10.0 & 188 & 68 & 3.9 \\
\hline 0 & 1500 & 0.6 & 24.4 & 14.4 & 32.3 & 10.7 & 202 & 72 & 4.0 \\
\hline 150 & 1500 & 0.5 & 18.3 & 9.6 & 31.5 & 9.9 & 234 & 76 & 4.1 \\
\hline 300 & 1500 & 1.4 & 15.5 & 20.4 & 32.6 & 8.8 & 264 & 79 & 4.3 \\
\hline \multicolumn{10}{|c|}{ Significance } \\
\hline D & & $\bullet$ & NS & - & $* *$ & NS & NS & NS & NS \\
\hline \multirow{2}{*}{\multicolumn{2}{|c|}{$\overrightarrow{\mathbf{B A}}$}} & $* * *$ & $* \infty$ & • & $*$ & $*$ & NS & Nis & $\mathrm{NS}$ \\
\hline \multirow{2}{*}{\multicolumn{2}{|c|}{$\begin{array}{l}\text { Linear } \\
\text { Quadratic }\end{array}$}} & $* * *$ & $* * *$ & - & * & * & NS & NS & NS \\
\hline & & NS & NS & NS & NS & NS & Nis & NS & NS \\
\hline \multicolumn{2}{|c|}{$\mathbf{B A} \times \mathbf{D}$} & & NS & NS & NS & * & NS & NS & NS \\
\hline
\end{tabular}

${ }^{\mathrm{z}}$ Means of 14 observations.

${ }^{\mathrm{y}}$ Means of $\approx 140$ observations.

${ }^{\mathrm{x}}$ Means of $\approx 70$ observations.

${ }^{\mathrm{w}}$ Means of 140 observations.

${ }^{*, * *, * * *, N S}$ Significant at $\mathrm{P}=0.05,0.01$, or 0.001 , or not significant, respectively.
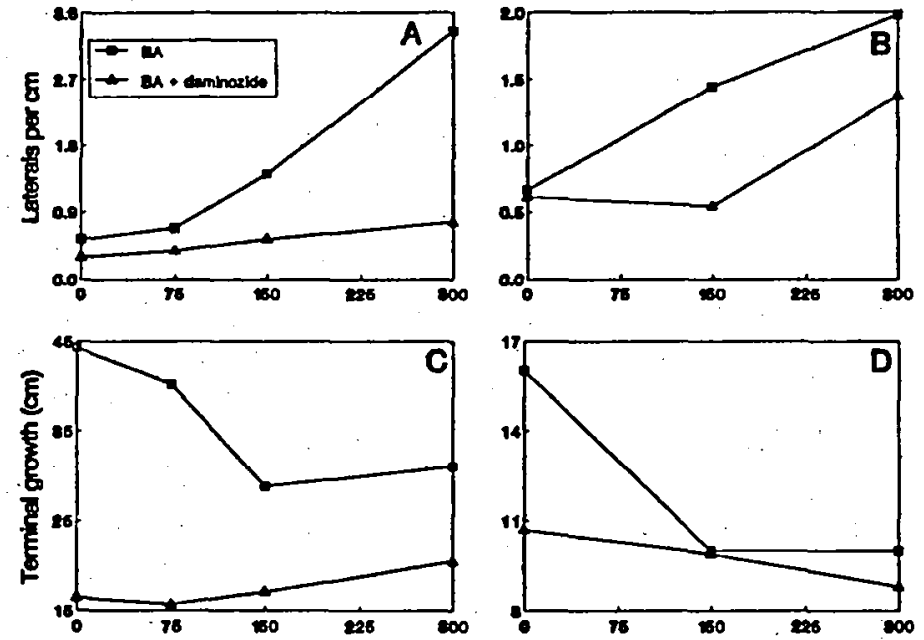

BA concentration ( $m g \cdot l i t e r^{-1}$ )

Fig. 1. Effects of 0 to $300 \mathrm{mg} \mathrm{BA} /$ liter alone or in combination with $1500 \mathrm{mg}$ daminozide/liter on growth of young 'Redspur Delicious' apples. (A, B) Lateral shoot growth. (C, D) Terminal shoot growth. Expt. 3: Fig. 1 A and C. Expt. 4: Fig. $1 \mathrm{~B}$ and D.

less branching induced by BA (Table 4). There was a BA $\times$ daminozide interaction on spur weight (Table 3), which increased when BA was applied in the absence, but not in the presence, of daminozide (Fig. 2A). Daminozide inhibited spurs on BA-treated trees from growing into lateral shoots.

Daminozide and BA increased bud weight and bud diameter (Table 3). There was a BA $\times$ daminozide interaction for both of these characteristics. Bud weight and bud diameter were always greater when BA was applied with daminozide (Fig. $2 \mathrm{C}$ and E). Bud weight and diameter were reduced by $300 \mathrm{mg} \mathrm{BA} /$ liter when applied alone, but when combined with daminozide, the size and weight of buds increased. Interactions between BA and daminozide and spur characteristics were not significant in Expt. 4 due primarily to variability (Table 4), although the pattern of responses were very similar (Fig. 2 D and F).
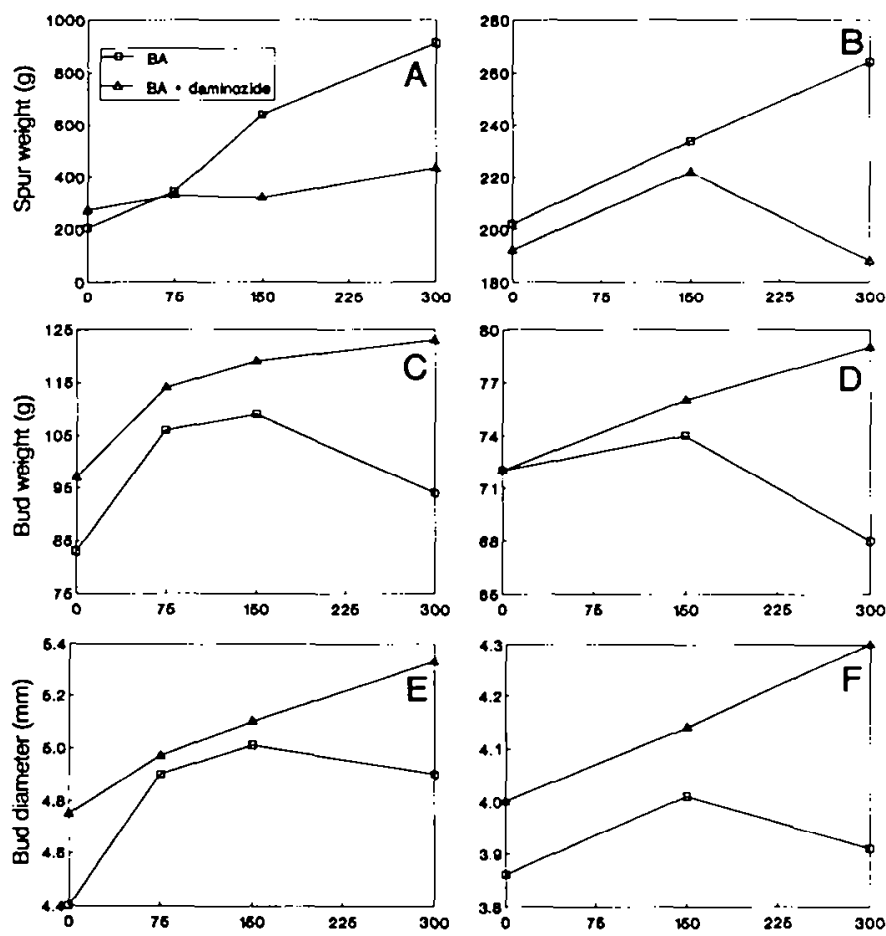

BA concentration (mg.liter ${ }^{-1}$ )

Fig. 2. Effects of 0 to $300 \mathrm{mg} \mathrm{BA} /$ liter alone or in combination with $1500 \mathrm{mg}$ daminozide/liter on spur quality of 'Redspur Delicious' apples. (A, B) Spur weight. (C, D) Spur bud weight. (E, F) Spur bud diameter. Expt. 3: Fig. 2 A, C, and E. Expt. 4: Fig. 2 B, D, and $\mathrm{F}$.

\section{Discussion}

$\mathrm{BA}$ alone or in combination with $\mathrm{GA}_{4+7}$ (Promalin) generally stimulates lateral branching on young trees when applied at concentrations of 250 to $500 \mathrm{mg} \cdot \mathrm{liter}^{-1}$ (Elfving, 1984, 1985; Forshey, 1982; Miller and Eldridge, 1986). In our study, lateral 
branching was stimulated at concentrations of BA as low as 100 mg.liter ${ }^{-P}$. Well-cared-for trees 4 to 5 years old are frequently vigorous and vegetative, and Greene and Miller (1988) have shown that there is an inverse relationship between tree vigor and BA concentrations required to stimulate lateral branching. Therefore, the branching response at low BA concentrations reported here may be attributed, at least in part, to the high growth potential of young, actively growing trees used in this investigation.

Lateral branch development may be beneficial to increase the bearing surface of young trees (Quinlan and Preston, 1978; Van Oosten, 1978). However, in our investigation, concentrations of BA that stimulated lateral branching also reduced cropping potential. BA is most effective at stimulating lateral branching after bloom when shoots are actively growing (Elfving, 1984; Miller and Eldridge, 1986), and this time period coincides with the time when BA is most active as a chemical thinner (Greene and Autio, 1989). Therefore, it appears that it may not be possible to stimulate lateral branching with this material on young trees just coming into production without sacrificing at least part of the crop.

There were several important BA $\times$ daminozide interactions on lateral branching, shoot growth, and spur vigor characteristics. BA stimulated spurs to grow into lateral shoots. The quality of these shoots as potential bearing units may have been reduced, since both bud weight and bud diameter were reduced by BA, and large bud size is one factor associated with spur vigor (Barritt et al., 1987). When daminozide was included with the BA, lateral branching was reduced, fewer spurs elongated, and the buds on these spurs were heavier and had a larger diameter. The positive effects of daminozide on B\&treated spurs were probably due to indirect effects on growth rather than to a direct effect of the chemical itself. Lateral branching on young apple trees may be reduced by daminozide (Greene and Lord, 1978), ethephon (Greene and Lord, 1978), paclobutrazol (Greene, 1988; Tukey, 1986), and flurprimidol (Tukey, 1986). Tukey (1989) reported increased spur formation, increased axillary bud development, and improved bearing wood when the growth retardant uniconazole was applied on apples in combination with BA; this was very similar to the response shown in this investigation.

Both lateral and terminal shoot growth w\&e reduced on trees treated with BA. A reduction in shoot growth -occurred when there was an increase in the number of actively growing shoots, which agrees with previous reports (Greene and Miller, 1988; Miller and Eldridge, 1986). The ultimate length of lateral shoots may be limited by the capacity of individual shoots to compete for available assimilates and hormones (Elfving, 1984; Greene and Miller, 1988). Direct growth retardation by daminozide is well documented (Greene and Lord, 1978); however, reduction in growth following BA application probably is an indirect effect due to intershoot competition (Greene and Miller, 1988). When BA was applied alone, the increase in total extension growth was caused by more spurs growing into lateral shoots. When BA and daminozide were applied together, growth retardation was caused primarily by daminozide, since daminozide inhibited the extension growth of lateral shoots and reduced the number of spurs that grew into lateral shoots;

A second application of BA made 3 weeks after the first caused no additional fruit thinning. This result was expected, since the second application was made when BA had little influence on fruit set (Greene and Autio, 1989). Lateral branching, extension shoot growth of spurs, and total growth were increased with a second BA application. Apparently, a previous daminozide application of $1500 \mathrm{mg} \cdot \mathrm{liter}^{-1}$ was insufficient to, prevent stimulation of spurs to grow into lateral shoots. Spur quality, as determined by bud weight and bud diameter, was reduced by a second $\mathrm{BA}$ application. There appears to be no advantage to applying BA as a split application.

BA had several beneficial effects on young apple trees just coming into production, namely, increased return bloom (Greene and Autio, 1990), increased lateral branching (Tables 1-4), and improved spur quality, especially when combined with a growth retardant such as daminozide (Tables 2 and 3). However, because BA is such an effective thinner, it may have limited value on trees just starting to produce, especially where preservation of the crop is desirable.

\section{Literature Cited}

Barritt, B.H., C.R. Rom, K.R. Guelich, S.R. Drake, and M.A. Dilley. 1987. Canopy position and light effects on spur, leaf, and fruit characteristics of 'Delicious' apples. HortScience 22:402-405.

Elfving, D.C. 1984. Factors affecting apple-tree responses to chemical branch-induction treatments. J. Amer. Soc. Hort. Sci. 109:476-481.

Elfving, D.C. 1985. Comparison of cytokinin and apical-dominanceinhibiting growth regulators for lateral-branch induction in nursery and orchard apple trees. J. Hort. Sci. 60:447-454.

Forshey, C.G. 1982. Branching responses of young apple trees to applications of 6-benzylamino purine and gibberellin $\mathrm{A}_{4+7}$. J. Amer. Soc. Hort. Sci. 107:538-541.

Greene, D.W. 1983. Some effects of AVG on fruit set, fruit characteristics, and vegetative growth of apple trees. J. Amer. Soc. Hort. Sci. 108:410-415

Greene, D.W. 1988. Reduced rates of paclobutrazol and multiple foliar sprays can effectively control 'Gardiner Delicious' growth. HortScience 23:742. (Abstr.)

Greene, D.W. and W.R. Autio. 1989. Evaluation of benzyladenine as a chemical thinner on 'McIntosh' apples. J. Amer. Soc. Hort. Sci. 114:68-73.

Greene, D.W. and W.J. Lord. 1978. Evaluation of scoring, limb spreading and growth regulators for increasing flower bud initiation and fruit set on young 'Delicious' apple trees. J. Amer. Soc. Hort. Sci. 103:208-210.

Greene, D.W. and P. Miller. 1988. Effects of growth regulator sprays and notching on growth and branching of 'Starkrimson Delicious' apple trees. J. Amer. Soc. Hort. Sci. 113:18-28.

Greene, D.W., W. Autio, and P. Miller. 1990. Thinning activity of benzyladenine on several apple cultivars. J. Amer. Soc. Hort. Sci. 115:349-400.

Kender, W.J. and S. Carpenter. 1972. Stimulation of lateral bud growth of apple trees by 6-benzylamino purine. J. Amer. Soc. Hort. Sci. $97: 377-380$

McLaughlin, J.M. and D.W. Greene. 1984. Effects of BA, $\mathrm{G}_{4+7}$, and daminozide on fruit set, fruit quality, vegetative growth, flower intiation, and flower quality of 'Golden Delicious' apples. J. Amer. Soc. Hort. Sci. 109:34-39.

Miller, S.S. and B.J. Eldridge. 1986. Use of 6-benzylamino purine and Promalin for improved canopy development in selected apple cultivars. Scientia Hort. 28:355-368.

Quinlan, J.D. and A.P. Preston. 1978. The use of branching agents to replace hand pruning of young trees of Bramley's Seedling apple. J. Hort. Sci. 53:39-43.

Tukey, L.D. 1986. Plant growth regulator absorption through the roots. Acta Hort. 179:199-206.

Tukey, L.D. 1989. Growth factors and plant regulators in the manipulation of plant development and cropping in tree fruits, p. 343361. In: C.J. Wright (ed.). Manipulation of flowering. Butterworths, London.

Van Oosten, H.J. 1978. Effect of initial tree quality on yield. Acta Hort. 65:123-127.

Yeager, A.F. 1916. A statistical study of the fruit-spur system of certain apple trees. Ore. Agr. Expt. Sta. Bul. 139. 